\title{
Antibacterial profiling of abietane-type diterpenoids
}

\section{Helfenstein, Andreas}

2017-01

pÿHelfenstein , A , Vahermo , M M A , Nawrot , D A, Demirci , F , 0_can , G , Krogerus , S , Yli-Kauhaluoma , J T , Moreira , V M \& Tammela , P S M 2017 , ' Antibacterial profiling of abietane-type diterpenoids ' , Bioorganic \& Medicinal Chemistry , vol. 25 , no. 1 , pp.

132-137 . https://doi.org/10.1016/j.bmc.2016.10.019

http://hdl.handle.net/10138/275040

https://doi.org/10.1016/j.bmc.2016.10.019

Downloaded from Helda, University of Helsinki institutional repository.

This is an electronic reprint of the original article.

This reprint may differ from the original in pagination and typographic detail.

Please cite the original version. 


\section{Antibacterial profiling of abietane-type diterpenoids}

Andreas Helfenstein ${ }^{a, \dagger}$, Mikko Vahermo, ${ }^{b, \dagger}$ Dorota A. Nawrot, ${ }^{a}$ Fatih Demirci, ${ }^{c}$ Gökalp İşcan, ${ }^{c}$ Sara

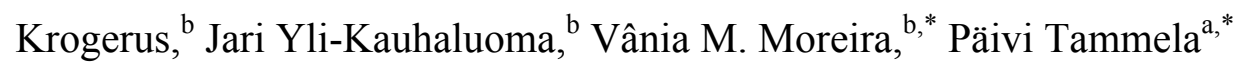

${ }^{a}$ Centre for Drug Research, Division of Pharmaceutical Biosciences, Faculty of Pharmacy, University of Helsinki, Viikinkaari 5 E (P.O. Box 56), FI-00014 University of Helsinki, Helsinki, Finland

${ }^{b}$ Division of Pharmaceutical Chemistry and Technology, Faculty of Pharmacy, University of Helsinki, Viikinkaari 5 E (P.O. Box 56), FI-00014 University of Helsinki, Helsinki, Finland ${ }^{c}$ Pharmacognosy Department, Faculty of Pharmacy, Anadolu University 26470-Eskişehir, Turkey

tThese authors contributed equally to this work

*Corresponding authors: Dr. Vânia M. Moreira, vania.moreira@helsinki.fi, p. +358-504480736; Dr. Päivi Tammela, paivi.tammela@helsinki.fi, p.+358-2941-59628 


\begin{abstract}
Abietic and dehydroabietic acid are interesting diterpenes with a highly diverse repertoire of associated bioactivities. They have, among others, shown antibacterial and antifungal activity, potentially valuable in the struggle against the increasing antimicrobial resistance and imminent antibiotic shortage. In this paper, we describe the synthesis of a set of 9 abietic and dehydroabietic acid derivatives containing amino acid side chains and their in vitro antimicrobial profiling against a panel of human pathogenic microbial strains. Furthermore, their in vitro cytotoxicity against mammalian cells was evaluated. The experimental results showed that the most promising compound was 10 [methyl $N$-(abiet-8,11,13-trien-18-yl)-D-serinate], with an $\mathrm{MIC}_{90}$ of $60 \mu \mathrm{g} / \mathrm{mL}$ against Staphylococcus aureus ATCC 25923, and $8 \mu \mathrm{g} / \mathrm{mL}$ against methicillin-resistant S. aureus, Staphylococcus epidermidis and Streptococcus mitis. The $\mathrm{IC}_{50}$ value for compound $\mathbf{1 0}$ against Balb/c 3 T3 cells was $45 \mu \mathrm{g} / \mathrm{mL}$.
\end{abstract}

Keywords: abietic acid; dehydroabietic acid; amino acid derivative; bacteria; fungi; cytotoxicity 


\section{Introduction}

The occurrence of antibiotic-resistant microorganisms is not a new phenomenon, but it has been getting more accentuated during recent years, partly due to the emergence of multidrug-resistant strains, together with a stagnating development of novel antibiotics. The spread of multidrugresistant bacteria and fungi poses a serious threat to the successful management of infections and has as such a growing impact on both quality and cost of the health care system. ${ }^{1}$ To face this challenge, not only improved antimicrobial stewardship, but also new antimicrobial drugs are needed. Natural products from plants, fungi and bacteria have a strong track record for having antimicrobial activity. Case in point, the screening of natural products for antibiotic activity has a higher success rate than an approach based on pure combinatorial chemistry. ${ }^{2}$ A pair of natural products that deserves our particular interest is found in many conifers around the globe: Abietic acid (1) and dehydroabietic acid (1a) (Scheme 1) are diterpenoids that boast an intriguing and wellstudied bioactivity profile, including antiviral, antibiotic and antifungal activity. ${ }^{3-5}$<smiles>CC(C)C1=CC2=CC[C@H]3[C@](C)(C(=O)O)CCC[C@]3(C)[C@H]2CC1</smiles>

1<smiles>CC(C)c1ccc2c(c1)CC[C@]1(C(=O)O)[C@@]2(C)CCC[C@]1(C)C(C)C</smiles>

$1 \mathrm{a}$<smiles>[Z6]C(=O)N[R](=O)[C@]1(C)CCC[C@@]2(C)[C@H]1CC=C1C=C(C(C)C)CC[C@@H]12</smiles>

2 - 8<smiles>COC(=O)[C@H](CO)NC(=O)[C@@]1(C)CCC[C@]2(C)c3ccc(C(C)C)cc3CC[C@@]12C</smiles>

9 (L) , 10 (D)
$2 \mathrm{R}=\mathrm{CH}_{2}$

$3 \mathrm{R}=\mathrm{CHCH}\left(\mathrm{CH}_{3}\right)_{2}$

$4 \mathrm{R}=\mathrm{CHCH}_{2} \mathrm{CH}_{3}$

$5 \mathrm{R}=\mathrm{CHCH}_{2} \mathrm{CH}\left(\mathrm{CH}_{3}\right)_{2}$

$6 \mathrm{R}=\mathrm{CHCH}_{2} \mathrm{Ph}$

$7 \mathrm{R}=\mathrm{CHCH}_{2}\left(\mathrm{C}_{6} \mathrm{H}_{11}\right)$

$8 \mathrm{R}=\mathrm{CHCH}_{2} \mathrm{OH}$

Scheme 1. Synthesis of compounds 2-10. i) EDC hydrochloride, HOBt, DIPEA, amino acid methyl ester hydrochloride, DMF, r.t. DIPEA $N, N$-diisopropylethylamine; DMF $=N, N$ dimethylformamide; EDC = 1-ethyl-3-(3-dimethylaminopropyl)carbodiimide; $\mathrm{HOBt}=\mathrm{N}$ hydroxybenzotriazole; THF = tetrahydrofuran 
The main source of $\mathbf{1}$ and $\mathbf{1 a}$ is the resin of pine trees (Pinus sp.), but they can also be found in many other conifers and are commercially available. ${ }^{6}$ Both $\mathbf{1}$ and $\mathbf{1 a}$ themselves have an intrinsic activity against (mainly Gram-positive) bacteria and fungi. ${ }^{6,7}$ The effort to enhance these activities has led to the synthesis of a multitude of diverse derivatives with reported antimicrobial activities, e.g. against Staphylococcus, Pseudomonas or Cladosporium sp. ${ }^{8-12}$

Besides their activities against bacteria and fungi, 1, 1a and their semi-synthetic derivatives also show potential in the fight against malaria and other protozoan diseases. ${ }^{13-15}$ While 1 itself is not toxic for human cells ${ }^{14}$, several derivatives of $\mathbf{1}$ and $\mathbf{1 a}$ - including some of their amino acid conjugates - exhibit moderate anti-proliferative properties against a panel of tumor cells lines. ${ }^{16,17}$ However, their effect on microorganisms has not been elucidated yet. In this paper, we investigated the antibacterial and antifungal properties of a series of abietane derivatives containing amino acid side chains.

Starting from $\mathbf{1}$ and 1a, a set of 9 derivatives was synthesized using carbodiimide coupling conditions in the presence of the corresponding amino acid methyl ester hydrochlorides. Following the synthesis, the abietanoyl amides were evaluated in several steps: we assessed the in vitro antimicrobial activity against Gram-positive (S. aureus) and Gram-negative (E. coli) bacteria and fungi (C. albicans) in a two-tiered screening assay. After a primary screening, the resulting hits served as a starting point for the synthesis of additional 2 derivatives, for which we established a dose-response relationship. In reference to the reports about cytotoxicity of $\mathbf{1}$ and $\mathbf{1 a}$ against tumor cells (see above), all active compounds were also studied for their in vitro cytotoxicity against noncancerous mammalian cells. In order to provide a better overview over compound bioactivity, we supplemented the data with additional explorative studies on their effect on opportunistic microorganisms. A database survey on known similar compounds and their reported mode of action completes this study.

\section{Materials and methods}

\subsection{Chemistry}

All reagents were obtained from Sigma Aldrich Co or TCI Europe if not otherwise stated. Abietic acid 1 (75\% purity) was obtained from Fluka. Dehydroabietic acid (1a, 90\% purity) was obtained from Pfaltz \& Bauer, USA. Compounds 1 and 1a used herein for the biological assays were 
recrystallized from methanol/water. (-)-2-Aminobutyric acid methyl ester hydrochloride was obtained from Bachem (Weil am Rhein, Germany) and $\beta$-cyclohexyl-L-alanine methyl ester hydrochloride was obtained from Novabiochem (Läufelfingen, Switzerland). For thin layer chromatography (TLC) analysis, Kieselgel $60 \mathrm{HF}_{254} /$ Kieselgel $60 \mathrm{G}$ was used (Merck). Flash column chromatography (FCC) was made with a Biotage high-performance flash chromatography Sp4system (Uppsala, Sweden) using a 0.1-mm pathlength flow cell UV-detector/recorder module (fixed wavelength: $254 \mathrm{~nm}$ ), and 12-mm or 25- $\mathrm{mm}$ flash cartridges. Melting points were recorded with an Electrothermal capillary tube melting point apparatus and are uncorrected. IR spectra were obtained using a Vertex 70 (Bruker Optics Inc., MA, USA) FTIR instrument. The FTIR measurements were made directly in solids with a horizontal attenuated total reflectance (ATR) accessory (MIRacle, Pike Technology, Inc, WI, USA). The transmittance spectra were recorded at a $4 \mathrm{~cm}^{-1}$ resolution between 4000 and $600 \mathrm{~cm}^{-1}$ using the OPUS 5.5 software (Bruker Optics Inc., MA, USA). NMR spectra were obtained using a Varian Mercury Plus 300 spectrometer, in $\mathrm{CDCl}_{3}$, with tetramethylsilane (TMS) as the internal standard. The chemical shifts were reported in parts per million (ppm) and on the $\delta$ scale from TMS as an internal standard. The coupling constants $J$ are quoted in Hertz (Hz). ESI-MS was performed by direct injection using a Synapt G2 HDMS (Waters, MA, USA) instrument.

Methyl $N$-(abieta-7,13-dien-18-yl)glycinate (2). Abietic acid 1 (188 mg; $0.622 \mathrm{mmol})$ was dissolved in DMF (2.5 mL), at room temperature. To this solution, a mixture of 1-ethyl-3-(3dimethylaminopropyl) carbodiimide (EDC) hydrochloride (239 $\mathrm{mg} ; 1.25 \mathrm{mmol}$ ) and $\mathrm{N}$ hydroxybenzotriazole (HOBt) monohydrate $(169 \mathrm{mg} ; 1.25 \mathrm{mmol})$ was added. The resulting mixture was left to agitate for $30 \mathrm{~min}$. Glycine methyl ester hydrochloride $(157 \mathrm{mg} ; 1.25 \mathrm{mmol})$ and $N, N$ diisopropylethylamine (DIPEA, $0.44 \mathrm{~mL} ; 2.5 \mathrm{mmol}$ ) were then added, and the reaction mixture was left to agitate for another hour after which the reaction was complete. The reaction mixture was suspended with diethyl ether $(50 \mathrm{~mL})$ and water $(8 \mathrm{~mL})$. The aqueous phase was further extracted with diethyl ether $(2 \times 50 \mathrm{~mL})$. The combined organic phases were washed with a $1 \mathrm{M}$ aqueous solution of $\mathrm{HCl}(20 \mathrm{~mL})$, a saturated aqueous solution of $\mathrm{NaHCO}_{3}(20 \mathrm{~mL})$, water $(20 \mathrm{~mL})$, and brine $(20 \mathrm{~mL})$, dried with anhydrous $\mathrm{Na}_{2} \mathrm{SO}_{4}$, filtered, and evaporated to dryness to give a yellowish oil (230 mg). It was purified by FCC using ethyl acetate: $n$-hexane (2.5:1) to yield compound 2 as a white solid (130 mg, 56\%). Mp 68-70 ${ }^{\circ} \mathrm{C}$. IR (ATR) 3374, 1749, 1640, 1520, $1207 \mathrm{~cm}^{-1} .{ }^{1} \mathrm{H}-\mathrm{NMR}$ $\left(300 \mathrm{MHz}, \mathrm{CDCl}_{3}\right) \delta 0.83(\mathrm{~s}, 3 \mathrm{H}), 0.99(\mathrm{~m}, 6 \mathrm{H}), 1.30(\mathrm{~s}, 3 \mathrm{H}), 3.74\left(\mathrm{~s}, 3 \mathrm{H}, \mathrm{OCH}_{3}\right), 4.00(\mathrm{~m}, 2 \mathrm{H},-$ $\left.\mathrm{NHCH}_{2}\right), 5.33(\mathrm{~d}, J=4.3 \mathrm{~Hz}, 1 \mathrm{H}, 7-\mathrm{H}), 5.74(\mathrm{~s}, 1 \mathrm{H}, 14-\mathrm{H}), 6.23(\mathrm{~m}, 1 \mathrm{H}, \mathrm{NH}) .{ }^{13} \mathrm{C}-\mathrm{NMR}(75 \mathrm{MHz}$, $\left.\mathrm{CDCl}_{3}\right) \delta 14.3,17.1,18.4,21,21.6,22.7,25.4,27.6,34.8,35,37.7,38.5,41.7,45.9,46.5,51.1$, 
52.4, 120.7, 122.6, 135.7, 145.3, 170.9 and $178.8\left(\mathrm{COOCH}_{3}\right.$ and $\left.\mathrm{CONH}\right) . \mathrm{HRMS}$ : calcd. for $\mathrm{C}_{23} \mathrm{H}_{36} \mathrm{NO}_{3} 374.2695[\mathrm{M}+1]^{+}$, found 374.2697.

Methyl $N$-(abieta-7,13-dien-18-yl)-L-valinate (3). Following the procedure for the preparation of 2, compound 3 was prepared from 1 (375 mg; $1.28 \mathrm{mmol}$ ), EDC hydrochloride (460 mg; 2.4 mmol), HOBt monohydrate (324 mg; $2.40 \mathrm{mmol}$ ), L-valine methyl ester hydrochloride (402 mg; $2.40 \mathrm{mmol})$, and DIPEA $(0.90 \mathrm{~mL} ; 5.1 \mathrm{mmol})$ in DMF $(5 \mathrm{~mL})$. The obtained yellow oil $(683 \mathrm{mg})$ was purified by FCC using ethyl acetate: $n$-hexane (2.5:1) to give compound 3 (230 mg, 45\%). Mp $55-57{ }^{\circ} \mathrm{C}$ IR (ATR) 3370, 1740, 1645, 1514, $1209 \mathrm{~cm}^{-1} .{ }^{1} \mathrm{H}-\mathrm{NMR}\left(300 \mathrm{MHz}, \mathrm{CDCl}_{3}\right) \delta 0.83$ (s, $3 \mathrm{H}), 0.91(\mathrm{~m}, 6 \mathrm{H}), 0.99(\mathrm{~m}, 6 \mathrm{H}), 1.30(\mathrm{~s}, 3 \mathrm{H}), 3.71\left(\mathrm{~s}, 3 \mathrm{H}, \mathrm{OCH}_{3}\right), 4.52\left(\mathrm{dd}, 1 \mathrm{H}, J_{1}=8.2 \mathrm{~Hz}\right.$ and $J_{2}$ $=4.7 \mathrm{~Hz}-\mathrm{NHC} \underline{\mathrm{H}}-), 5.33(\mathrm{~d}, J=4.9 \mathrm{~Hz}, 1 \mathrm{H}, 7-\mathrm{H}), 5.74(\mathrm{~s}, 1 \mathrm{H}, 14-\mathrm{H}), 6.20(\mathrm{~d}, J=8.2 \mathrm{~Hz}, 1 \mathrm{H}, \mathrm{NH})$. ${ }^{13} \mathrm{C}-\mathrm{NMR}\left(75 \mathrm{MHz}, \mathrm{CDCl}_{3}\right) \delta 14.2,17.1,18.1,18.4,19.1,20.9,21.5,22.6,25.5,27.5,31.3,34.7$, $35,37.8,38.4,45.6,46.6,51,52.1,57.3,120.5,122.6,135.6,145.2,172.9$ and $178.2\left(\mathrm{COOCH}_{3}\right.$ and CONH). HRMS: calcd. for $\mathrm{C}_{26} \mathrm{H}_{42} \mathrm{NO}_{3} 416.3165[\mathrm{M}+1]^{+}$, found 416.3169 .

Methyl $N$-(abieta-7,13-dien-18-yl)-L-ethylglycinate (4). Following the procedure for the preparation of 2, compound 4 was prepared from 1 (375 mg; $1.28 \mathrm{mmol}$ ), EDC hydrochloride (460 mg; $2.4 \mathrm{mmol}$ ), HOBt monohydrate (324 mg; $2.40 \mathrm{mmol}$ ), L-aminobutyric acid methyl ester hydrochloride (369 mg; $2.40 \mathrm{mmol}$ ), and DIPEA (0.90 mL; $5.1 \mathrm{mmol})$ in DMF (5 mL) as a yellow solid (671 mg). Purification by FCC using ethyl acetate: $n$-hexane (2.5:1) gave compound 4 (189 mg, 38\%). Mp 59-71 ${ }^{\circ} \mathrm{C}$ IR (ATR) 3357, 1742, 1639, 1520, $1212 \mathrm{~cm}^{-1} .{ }^{1} \mathrm{H}-\mathrm{NMR}\left(300 \mathrm{MHz}, \mathrm{CDCl}_{3}\right) \delta$ $0.83(\mathrm{~s}, 3 \mathrm{H}), 0.89\left(\mathrm{t}, J=7.5 \mathrm{~Hz}, 3 \mathrm{H},-\mathrm{CH}_{2} \mathrm{CH}_{3}\right), 0.99(\mathrm{~m}, 6 \mathrm{H}), 1.29(\mathrm{~s}, 3 \mathrm{H}), 3.73\left(\mathrm{~s}, 3 \mathrm{H}, \mathrm{OCH}_{3}\right), 4.53(\mathrm{~m}, 1 \mathrm{H}$, -NHCH), $5.33(\mathrm{~m}, 1 \mathrm{H}, 7-\mathrm{H}), 5.74(\mathrm{~s}, 1 \mathrm{H}, 14-\mathrm{H}), 6.23(\mathrm{~d}, J=7.3 \mathrm{~Hz}, 1 \mathrm{H}, \mathrm{NH}) .{ }^{13} \mathrm{C}-\mathrm{NMR}\left(75 \mathrm{MHz}, \mathrm{CDCl}_{3}\right) \delta$ 9.8, 14.3, 17.1, 18.4, 21, 21.6, 22.6, 25.4, 25.6, 27.6, 34.8, 35, 37.7, 38.4, 45.8, 46.5, 51.1, 52.14, 53.6, 120.6, 122.6, 135.7, 145.3, 173.4 and $178.2\left(\mathrm{COOCH}_{3}\right.$ and $\left.\mathrm{CONH}\right)$. HRMS: calcd. for $\mathrm{C}_{25} \mathrm{H}_{40} \mathrm{NO}_{3}$ $402.3008[\mathrm{M}+1]^{+}$, found 402.3010 .

Methyl $N$-(abieta-7,13-dien-18-yl)-L-leucinate (5). Following the procedure for the preparation of 2, compound 5 was prepared from 1 (375 mg; $1.28 \mathrm{mmol}$ ), EDC hydrochloride (460 mg; 2.4 mmol), HOBt monohydrate (324 mg; $2.40 \mathrm{mmol}$ ), L-leucine methyl ester hydrochloride (436 mg; $2.40 \mathrm{mmol})$, and DIPEA $(0.90 \mathrm{~mL} ; 5.1 \mathrm{mmol})$ in DMF $(5 \mathrm{~mL})$ as a yellowish solid $(580 \mathrm{mg})$. Purification by FCC using ethyl acetate: $n$-hexane (2.5:1) gave compound 5 (150 mg, 28\%). Mp 88$90{ }^{\circ} \mathrm{C}$. IR (ATR) 3325, 1745, 1631, 1518, $1200 \mathrm{~cm}^{-1} .{ }^{1} \mathrm{H}-\mathrm{NMR}\left(300 \mathrm{MHz}, \mathrm{CDCl}_{3}\right) \delta 0.83(\mathrm{~s}, 3 \mathrm{H})$, $0.94\left(\mathrm{dd}, J_{1}=6 \mathrm{~Hz}\right.$ and $\left.J_{2}=3.4 \mathrm{~Hz}, 6 \mathrm{H},-\mathrm{CH}_{2}\left(\mathrm{CH}_{3}\right)_{2}\right), 1.00(\mathrm{~m}, 6 \mathrm{H}), 1.29(\mathrm{~s}, 3 \mathrm{H}), 3.71(\mathrm{~s}, 3 \mathrm{H}$,

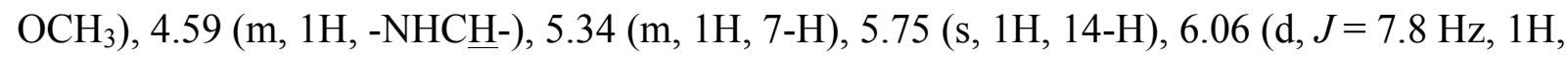


$\mathrm{NH}) .{ }^{13} \mathrm{C}-\mathrm{NMR}\left(75 \mathrm{MHz}, \mathrm{CDCl}_{3}\right) \delta 14.3,17.1,18.4,21,21.6,22.2,22.6,23,25.2,25.4,27.6,34.8$, $35,37.8,38.5,41.8,45.8,46.5,51.1,52.3,120.7,122.6,135.7,145.3,174$ and $178.3\left(\mathrm{COOCH}_{3}\right.$ and CONH). HRMS: calcd. for $\mathrm{C}_{27} \mathrm{H}_{44} \mathrm{NO}_{3} 430.3321[\mathrm{M}+1]^{+}$, found 430.3320 .

Methyl $N$-(abieta-7,13-dien-18-yl)-L-phenylalaninate (6). Following the procedure for the preparation of 2, compound $\mathbf{6}$ was prepared from 1 (375 mg; $1.28 \mathrm{mmol})$, EDC hydrochloride (460 mg; $2.4 \mathrm{mmol}$ ), HOBt monohydrate (324 mg; $2.40 \mathrm{mmol})$, L-phenylalanine methyl ester hydrochloride (518 $\mathrm{mg} ; 2.40 \mathrm{mmol})$, and DIPEA $(0.90 \mathrm{~mL} ; 5.1 \mathrm{mmol})$ in DMF (5 mL) as a yellow solid (740 mg). Purification by FCC using ethyl acetate: $n$-hexane (2.5:1) gave compound 6 (170 mg, 30\%). Mp 67-69 ${ }^{\circ} \mathrm{C}$. IR (ATR) 3361, 1749, 1628, 1521, $1211 \mathrm{~cm}^{-1}$. ${ }^{1} \mathrm{H}-\mathrm{NMR}(300 \mathrm{MHz}$, $\left.\mathrm{CDCl}_{3}\right) \delta 0.83(\mathrm{~s}, 3 \mathrm{H}), 1.00(\mathrm{~m}, 6 \mathrm{H}), 1.19\left(\mathrm{~s}, 3 \mathrm{H}, 19-\mathrm{CH}_{3}\right), 3.10\left(\mathrm{ddd}, J_{1}=20.7 \mathrm{~Hz}, J_{2}=13.4 \mathrm{~Hz}\right.$, and $\left.J_{3}=6.3 \mathrm{~Hz}, 2 \mathrm{H}, \underline{\mathrm{CH}}_{2} \mathrm{Ph}\right), 3.71\left(\mathrm{~s}, 3 \mathrm{H}, \mathrm{OCH}_{3}\right), 4.83(\mathrm{~m}, 1 \mathrm{H}, \mathrm{NHCH}), 5.26(\mathrm{~m}, 1 \mathrm{H}, 7-\mathrm{H}), 5.74(\mathrm{~s}$, $1 \mathrm{H}, 14-\mathrm{H}), 6.09\left(\mathrm{~d}, J_{1}=7.3 \mathrm{~Hz}, 1 \mathrm{H}, \mathrm{NH}\right), 7.11(\mathrm{~m}, 2 \mathrm{H}$, aromatic- $\mathrm{H}), 7.28(\mathrm{~m}, 3 \mathrm{H}$, aromatic- $\mathrm{H}) .{ }^{13} \mathrm{C}-$ NMR (75 MHz, $\left.\mathrm{CDCl}_{3}\right) \delta 14.3,17,18.4,21,21.6,22.6,25.3,27.6,34.8,35,37.7,38.1,38.4,45.7$, 46.5, 51.1, 52.4, 53.4, 120.7 (aromatic-C), 122.6 (aromatic-C), 127.3 (aromatic-C), 128.8 (aromaticC), 129.4 (aromatic-C), 135.6 (aromatic-C), 136.3 (aromatic-C), 145.2 (aromatic-C), 172.6 and 178.1 ( $\mathrm{COOCH}_{3}$ and $\left.\mathrm{CONH}\right)$. HRMS: calcd. for $\mathrm{C}_{30} \mathrm{H}_{42} \mathrm{NO}_{3} 464.3165[\mathrm{M}+1]^{+}$, found 464.3166.

Methyl $N$-(abieta-7,13-dien-18-yl)cyclohexyl-L-alaninate (7). Following the procedure for the preparation of 2, compound 7 was prepared from 1 (188 mg; $0.622 \mathrm{mmol}$ ), EDC hydrochloride (239 $\mathrm{mg}$; $1.25 \mathrm{mmol}$ ), HOBt monohydrate (169 mg; $1.25 \mathrm{mmol}$ ), $\beta$-cyclohexyl-L-alanine methyl ester hydrochloride (266 mg; $2.40 \mathrm{mmol})$, and DIPEA $(0.44 \mathrm{~mL} ; 2.5 \mathrm{mmol})$ in DMF $(2.5 \mathrm{~mL})$ as a yellow oil (380 mg). Purification by FCC using ethyl acetate: $n$-hexane (2.5:1) gave compound 7 (141 mg, 48\%). Mp 108-110 ${ }^{\circ} \mathrm{C}$. IR (ATR) 3374, 1744, 1634, 1521, $1202 \mathrm{~cm}^{-1} .{ }^{1} \mathrm{H}-\mathrm{NMR}$ (300 $\left.\mathrm{MHz}_{\mathrm{CDCl}}\right) \delta 0.84(\mathrm{~s}, 3 \mathrm{H}), 1.00(\mathrm{~m}, 6 \mathrm{H}), 1.29(\mathrm{~s}, 3 \mathrm{H}), 3.71\left(\mathrm{~s}, 3 \mathrm{H}, \mathrm{OCH}_{3}\right), 4.63(\mathrm{~m}, 1 \mathrm{H}, \mathrm{NHCH}-)$, $5.35(\mathrm{~m}, 1 \mathrm{H}, 7-\mathrm{H}), 5.75(\mathrm{~s}, 1 \mathrm{H}, 14-\mathrm{H}), 6.04(\mathrm{~d}, J=7.7 \mathrm{~Hz}, 1 \mathrm{H}, \mathrm{NH}) .{ }^{13} \mathrm{C}-\mathrm{NMR}\left(75 \mathrm{MHz}, \mathrm{CDCl}_{3}\right) \delta$ $14.3,17.1,18.4,21,21.6,22.6,25.4,26.3,26.4,26.5,27.6,32.7,33.7,34.6,34.8,35,37.7,38.5$, $40.1,45.8,46.5,50.4,51.1,52.4,120.6,122.6,135.7,145.3,174.1$ and $178.2\left(\mathrm{COOCH}_{3}\right.$ and CONH). HRMS: calcd. for $\mathrm{C}_{30} \mathrm{H}_{48} \mathrm{NO}_{3} 470.3634[\mathrm{M}+1]^{+}$, found 470.3636 .

Methyl $N$-(abieta-7,13-dien-18-yl)-L-serinate (8). Following the procedure for the preparation of 2, compound 8 was prepared from 1 (188 mg; $0.622 \mathrm{mmol})$, EDC hydrochloride (239 mg; 1.25 mmol), HOBt monohydrate (169 mg; $1.25 \mathrm{mmol}$ ), L-serine methyl ester hydrochloride (195 mg; $2.40 \mathrm{mmol})$, and DIPEA (0.44 mL; $2.5 \mathrm{mmol})$ in DMF $(2.5 \mathrm{~mL})$ as a yellow solid $(239 \mathrm{mg})$. Purification by FCC using ethyl acetate: $n$-hexane (2.5:1) gave compound 8 ( $80 \mathrm{mg}, 32 \%)$. Mp 64- 
$66{ }^{\circ} \mathrm{C}$. IR (ATR) 3404, 1743, 1634, 1516, $1207 \mathrm{~cm}^{-1} .{ }^{1} \mathrm{H}-\mathrm{NMR}\left(300 \mathrm{MHz}, \mathrm{CDCl}_{3}\right) \delta 0.83(\mathrm{~s}, 3 \mathrm{H})$, $0.99(\mathrm{~m}, 6 \mathrm{H}), 1.32(\mathrm{~s}, 3 \mathrm{H}), 3.77\left(\mathrm{~s}, 3 \mathrm{H}, \mathrm{OCH}_{3}\right), 3.92$ (d, J=4.1 Hz, 2H, $\left.\underline{\mathrm{H}}_{2} \mathrm{OH}\right), 4.63(\mathrm{~m}, 1 \mathrm{H}$, NHCH- $), 5.34$ (m, 1H, 7-H), $5.74(\mathrm{~s}, 1 \mathrm{H}, 14-\mathrm{H}), 6.71$ (d, $J=5.9 \mathrm{~Hz}, 1 \mathrm{H}, \mathrm{NH}) .{ }^{13} \mathrm{C}-\mathrm{NMR}(75 \mathrm{MHz}$, $\left.\mathrm{CDCl}_{3}\right) \delta 14.3,17.1,18.4,21,21.6,22.6,25.5,27.6,34.8,35.1,37.5,38.4,45.9,46.6,51.1,53$, 55.3, $63.9\left(\mathrm{CH}_{2} \mathrm{OH}\right), 120.5,122.5,135.7,145.5,171.3$ and $179.4\left(\mathrm{COOCH}_{3}\right.$ and $\left.\mathrm{CONH}\right)$. HRMS: calcd. for $\mathrm{C}_{24} \mathrm{H}_{38} \mathrm{NO}_{4} 404.2801[\mathrm{M}+1]^{+}$, found 404.2803 .

Methyl $N$-(abiet-8,11,13-trien-18-yl)-L-serinate (9). Following the procedure for the preparation of 2, compound 9 was prepared from 1a $(250 \mathrm{mg}$; $0.83 \mathrm{mmol})$, EDC hydrochloride $(239 \mathrm{mg}$; 1.25 mmol), HOBt monohydrate (169 mg; $1.25 \mathrm{mmol}$ ), L-serine methyl ester hydrochloride (194 mg; $1.25 \mathrm{mmol})$, and DIPEA (0.44 mL; $2.5 \mathrm{mmol})$ in DMF (2.5 mL). Compound 9 (304 mg, 91\%): Mp 103-104 ${ }^{\circ} \mathrm{C}$. IR (ATR) 3404, 1745, 1639, 1515, 1500, 1209, $821 \mathrm{~cm}^{-1} .{ }^{1} \mathrm{H}-\mathrm{NMR}\left(\mathrm{CDCl}_{3}\right) \delta 1.21(\mathrm{~s}$, $3 \mathrm{H}), 1.23(\mathrm{~s}, 3 \mathrm{H}), 1.24(\mathrm{~s}, 3 \mathrm{H}), 1.32(\mathrm{~s}, 3 \mathrm{H}), 2.14\left(\mathrm{dd}, J_{l}=12.4 \mathrm{~Hz}\right.$ and $\left.J_{2}=2.1 \mathrm{~Hz}, 1 \mathrm{H}\right), 2.32(\mathrm{~d}, J$ $=11.4 \mathrm{~Hz}, 1 \mathrm{H}), 2.85(\mathrm{~m}, 3 \mathrm{H}), 3.78\left(\mathrm{~s}, 3 \mathrm{H}, \mathrm{OCH}_{3}\right), 3.93\left(\mathrm{~m}, 2 \mathrm{H},-\mathrm{CH}_{2} \mathrm{OH}\right), 4.68(\mathrm{~m}, 1 \mathrm{H},-\mathrm{NHC} \underline{\mathrm{H}}-)$, $6.73(\mathrm{~d}, J=7.1 \mathrm{~Hz}, 1 \mathrm{H}, \mathrm{NH}), 6.87(\mathrm{~s}, 1 \mathrm{H}, 14-\mathrm{H}), 6.99\left(\mathrm{dd}, J_{l}=8.2 \mathrm{~Hz}\right.$ and $J_{2}=1.8 \mathrm{~Hz}, 1 \mathrm{H}$, aromatic-H), $7.16\left(\mathrm{~d}, J=8.2 \mathrm{~Hz}, 1 \mathrm{H}\right.$, aromatic-H). ${ }^{13} \mathrm{C}-\mathrm{NMR}\left(75 \mathrm{MHz}, \mathrm{CDCl}_{3}\right) \delta 16.3,18.6,21.1$, 23.9, 25.2, 30, 33.4, 37.1, 37.2, 37.9, 45.6, 47.4, 52.6, 54.8, 63.6, 123.9 (aromatic-C), 124 (aromatic-C), 126.8 (aromatic-C), 134.5 (aromatic-C), 145.7 (aromatic-C), 146.7 (aromatic-C), 171.1 and $179.1\left(\mathrm{COOCH}_{3}\right.$ and $\left.\mathrm{CONH}\right)$. HRMS: calcd. for $\mathrm{C}_{24} \mathrm{H}_{36} \mathrm{NO}_{4} 402.2644[\mathrm{M}+1]^{+}$, found 402.2641 .

Methyl $N$-(abiet-8,11,13-trien-18-yl)-D-serinate (10). Following the procedure for the preparation of 2, compound 10 was prepared from $1 \mathbf{a}(700 \mathrm{mg} ; 2.33 \mathrm{mmol})$, EDC hydrochloride $(670 \mathrm{mg} ; 3.49$ mmol), HOBt monohydrate (472 mg; $3.49 \mathrm{mmol}$ ), D-serine methyl ester hydrochloride (544 mg; $3.49 \mathrm{mmol})$ and DIPEA (1.22 mL; $6.93 \mathrm{mmol})$ in DMF (7 mL). Compound 10 (911 mg, 97\%): Mp $52-53{ }^{\circ} \mathrm{C}$. IR (ATR) 3400, 1741, 1639, 1517, 1515, 1211, $821 \mathrm{~cm}^{-1} .{ }^{1} \mathrm{H}-\mathrm{NMR}\left(\mathrm{CDCl}_{3}\right) \delta 1.20(\mathrm{~s}$, $3 \mathrm{H}), 1.23(\mathrm{~s}, 3 \mathrm{H}), 1.23(\mathrm{~s}, 3 \mathrm{H}), 1.32(\mathrm{~s}, 3 \mathrm{H}), 2.13\left(\mathrm{dd}, J_{l}=12.4 \mathrm{~Hz}\right.$ and $\left.J_{2}=1.9 \mathrm{~Hz}, 1 \mathrm{H}\right), 2.32(\mathrm{~d}, J$ $=12.7 \mathrm{~Hz}, 1 \mathrm{H}), 2.86(\mathrm{~m}, 3 \mathrm{H}), 3.78\left(\mathrm{~s}, 3 \mathrm{H}, \mathrm{OCH}_{3}\right), 3.92\left(\mathrm{ddd}, J_{1}=24 \mathrm{~Hz}, J_{2}=11.1\right.$, and $\mathrm{J}_{3}=3.8 \mathrm{~Hz}$, 2H, $\left.-\mathrm{CH}_{2} \mathrm{OH}\right), 4.68$ (m, 1H, -NHCH- $), 6.73$ (d, J=7.1 Hz, 1H, NH), 6.86 (s, 1H, 14-H), 6.99 (dd, $J_{1}=8.2 \mathrm{~Hz}$ and $J_{2}=1.6 \mathrm{~Hz}, 1 \mathrm{H}$, aromatic-H), $7.16\left(\mathrm{~d}, J=8.2 \mathrm{~Hz}, 1 \mathrm{H}\right.$, aromatic-H). ${ }^{13} \mathrm{C}-\mathrm{NMR}(75$ $\left.\mathrm{MHz}_{\mathrm{CDCl}}\right) \delta 16.3,18.6,21,23.9,23.9,25.2,30,33.4,37.1,37.2$, 37.9, 45.6, 47.4, 52.6, 54.8, 63.5, 123.9 (aromatic-C), 124 (aromatic-C), 126.8 (aromatic-C), 134.5 (aromatic-C), 145.7 (aromatic-C), 146.8 (aromatic-C), 171.2 and 179.1 ( COOCH$_{3}$ and $\left.\mathrm{CONH}\right)$. HRMS: calcd. for $\mathrm{C}_{24} \mathrm{H}_{36} \mathrm{NO}_{4} 402.2644[\mathrm{M}+1]^{+}$, found 402.2643 . 
Compounds 2, 4, 7 and $\mathbf{1 0}$ are novel. For the bioactivity testing, all compounds were initially dissolved in DMSO and, whenever possible, used as freshly prepared solutions to prevent degradation.

\subsection{Evaluation of antimicrobial activity}

Antimicrobial activity was evaluated in a two-tiered screening set-up. In a primary screen, we exposed three strains (E. coli, S. aureus and C. albicans) to the initial set of compounds. Compounds that inhibited the growth by at least $75 \%$ were then confirmed in a secondary evaluation, together with compounds 9 and 10. This step provided information about the doseresponse relationship. Both steps followed the CLSI and NCCLS broth microdilution protocols for antimicrobial testing, ${ }^{18-19}$ and the assays were carried out at least in triplicate.

E. coli ATCC 25922, S. aureus ATCC 25923 and C. albicans ATCC 90028 were obtained from Microbiologics Inc. (St. Cloud, MN). For the assays, bacteria were grown in Mueller-Hinton broth (MHB, Becton Dickinson, Sparks, MD) overnight at $37^{\circ} \mathrm{C}$; C. albicans was cultured on Sabouraud dextrose agar (SDA, Becton Dickinson) for $48 \mathrm{~h}$ at $30^{\circ} \mathrm{C}$. Compounds and controls were added to the plate, and the microorganisms were then seeded into 96-well plates (Thermo Fisher Scientific, Roskilde, DK) with inocula of $5 \times 10^{5} \mathrm{CFU} / \mathrm{mL}$ in MHB for bacteria and $1 \times 10^{4} \mathrm{CFU} / \mathrm{mL}$ in RPMI 1640 (Gibco, Paisley, UK) for fungi. Each plate carried a negative control (media and DMSO) and antimicrobial agent as positive control at $\operatorname{MIC}_{90}(S$. aureus: ciprofloxacin $1 \mu \mathrm{g} / \mathrm{mL}$; E. coli: gentamicin $2 \mu \mathrm{g} / \mathrm{mL}$; C. albicans: amphotericin B $16 \mu \mathrm{g} / \mathrm{mL}$.

In the primary screening, all compounds were tested at a concentration of $50 \mu \mathrm{M}$ and dose-response experiments with a dilution series were carried out as secondary evaluation.

Plates were incubated for $24 \mathrm{~h}$ (C. albicans: $48 \mathrm{~h}$ ), and absorbance was measured at $620 \mathrm{~nm}$ on a Victor 1420 plate reader (PerkinElmer Life Sciences, Turku, Finland). The percentage of inhibition was calculated by comparing the optical density at $620 \mathrm{~nm}\left(\mathrm{OD}_{620}\right)$ of the bacterial suspension with and without the compound (negative control).

Since the compounds $\mathbf{9}$ and $\mathbf{1 0}$ showed activity against $S$. aureus, we carried out additional experiments to determine the minimum inhibitory concentrations $\left(\mathrm{MIC}_{90}\right.$ ) against $S$. aureus ATCC 4330 (MRSA) and an array of microorganisms that are commonly responsible for food poisoning and spoilage or dermatological and dental problems (Salmonella typhimurium ATCC 
13311, Staphylococcus epidermidis ATCC 12228, Propionibacterium acnes ATCC 6919, Streptococcus mitis NCIMB 13770, Rhodotorula mucilaginosa ATCC 66034, Cladosporium cladosporioides ATCC 16022).

Assays were carried out in similar manner as described above following the CLSI and NCCLS guidelines for broth microdilution methods. ${ }^{18-19}$. Dilution series of antimicrobial standards chloramphenicol, tetracycline, ampicillin, clotrimazole, fluconazole, and nystatin were used as positive controls in the assays ( $\mathrm{MIC}_{90}$ values are presented in Table 2).

\subsection{Cytotoxicity assays on mammalian cells}

Cytotoxicity was assessed against the BALB/c 3T3 mouse embryonic fibroblast cell line, obtained from ECACC (UK) and grown in DMEM (Sigma-Aldrich, USA), supplemented with 5\% fetal bovine serum (FBS, Gibco, USA), 5\% new-born calf serum (NCS, Gibco, USA), $292 \mu \mathrm{g} / \mathrm{mL}$ Lglutamine, $100 \mathrm{IU} / \mathrm{mL}$ penicillin and $100 \mu \mathrm{g} / \mathrm{mL}$ streptomycin. Cells were incubated at $37^{\circ} \mathrm{C}, 5 \%$ of $\mathrm{CO}_{2}$, and $95 \%$ humidity. For the assays, cells were seeded into clear Nunc 96-well microplates (Thermo Fisher Scientific, Roskilde, DK) at a density of 10,000 cells/well. After overnight incubation, cells were exposed to the compounds for $24 \mathrm{~h}$. Polymyxin B sulphate $(15,000 \mathrm{IU} / \mathrm{mL})$, which is toxic for BALB/c $3 \mathrm{~T} 3$ cells, was used as a positive control on every assay plate. The compounds were diluted with assay media with 5\% serum and 1\% DMSO. Cytotoxicity of the optimized compounds was measured using 3-(4,5-dimethylthiazol-2-yl)-2,5-diphenyltetrazolium (MTT) and lactate dehydrogenase (LDH) assays. In the MTT assay, viable cells reduce MTT to the purple-colored formazan, which can then be quantified. ${ }^{20} 10 \mu \mathrm{L}$ of MTT solution $(5 \mathrm{mg} / \mathrm{mL}$ in sterile PBS, $\mathrm{pH}$ 7.4) were added to each well, and the plate was incubated for $3 \mathrm{~h}$. After removing the media, the formazan crystals were dissolved in DMSO, and absorbance was measured at $550 \mathrm{~nm}$ and $655 \mathrm{~nm}$ (background). The LDH assay measures the release of LDH from cells with a damaged cell membrane. The assay was carried out using CytoTox-ONETM Homogeneous Membrane Integrity Assay (Promega, Madison, WI) according to the manufacturer's instructions. ${ }^{21}$ Both assays were first carried out with four compound concentrations between 10-40 $\mu \mathrm{g} / \mathrm{mL}$, and compounds exhibiting cytotoxicity in that range were then re-tested with eight concentrations ranging from $10-80 \mu \mathrm{g} / \mathrm{mL}$ to determine $\mathrm{IC}_{50}$ values. The values were computed with OriginPro 8.6 (OriginLab Corp, Northampton, MA, USA). 


\subsection{Search for related compounds in online databases}

In order to survey supplementary information about bioactivity of similar compounds, as well as to postulate a possible mode of action, we searched the ChEMBL and PubChem databases for chemically similar structures (similarity threshold of 90). This was done using ChEMBL web services, but due to the technical limitations of the interface, some stereochemical properties of the molecules could not be submitted. We examined the returned literature lists to gather information about bioactivities reported for similar compounds and, if applicable, for their mode of action. We also compared molecular fingerprints of the active compounds with known antibiotics. The structures were retrieved from ChEMBL by searching for ATC code "J". We then calculated the Tanimoto similarity between the optimized compound set and the known anti-infectives using RDKit.

\section{Results and discussion}

Abietic acid (1) has been widely studied for its bioactivity, and our findings reinforce its position as a promising parent structure for the synthesis of novel, bioactive compounds. They contribute to the body of knowledge related to compound 1 and deepen the understanding of the potential and properties of 1 and its derivatives.

\subsection{Antimicrobial screening}

As a response to the upcoming shortage of potent antibiotics, this study first and foremost aimed to evaluate the antimicrobial potential of amino acid derivatives of abietic acid (1). Although the antiproliferative activity of amino acid-based derivatives of $\mathbf{1}$ has been previously reported, ${ }^{17,22}$ there is yet no detailed study to address their potential antimicrobial properties. Moreover, our previous work showed that the combination of amino acids with an abietane core, such as that of $\mathbf{1 a}$, resulted in potent antimicrobial and anti-biofilm agents, ${ }^{11,12}$ which suggests that this type of modification is worth pursuing when designing compounds with potential antimicrobial effects. In previous publications, abietic acid $\mathbf{1}$ and related compounds have been shown to be effective mostly against Gram-positive bacteria. ${ }^{3,23}$ Some Gram-negative bacteria - including certain strains of $E$. colihave, however, been reported to show capability to degrade both $\mathbf{1}$ and dehydroabietic acid (1a). ${ }^{24}$ Based on these findings, it was not surprising that $\mathbf{1}$ itself revealed an - albeit modest - inhibitory 
effect against $S$. aureus, but not against $C$. albicans or $E$. coli (Table 1 ). In the primary screen at $50 \mu \mathrm{M}(20 \mu \mathrm{g} / \mathrm{mL})$ concentration, 1 inhibited the growth of $S$. aureus by $44 \%$, a value surpassed only by compound 8 (76\% inhibition). Compound $\mathbf{8}$ moderately inhibited also the growth of C. albicans (39\%). Based on the activity of $\mathbf{8}$ against $S$. aureus, we subsequently synthesized two additional compounds, 9 and 10, starting from $1 \mathrm{a}$ instead of $\mathbf{1}$, in an attempt to generate potentially more chemically stable compounds by replacing the conjugated diene system of $\mathbf{1}$ with the aromatic ring of 1a. In addition, compound 9 bears the same L-serine based side-chain as compound $\mathbf{8}$ whereas compound $\mathbf{1 0}$ bears a D-serine based side-chain.

Table 1. Primary screening results for compounds 1-8. The table shows the inhibition of growth $(\%) \pm \mathrm{SD}(n=3)$ at $50 \mu \mathrm{M}$ concentration after $24 \mathrm{~h}$ incubation (48 h for C. albicans). The growth was determined by measuring the optical density at $620 \mathrm{~nm}$. Antimicrobial agents were used as positive controls at $\mathrm{MIC}_{90}$ : S. aureus, ciprofloxacin $1 \mu \mathrm{g} / \mathrm{mL} ;$ E. coli, gentamicin $2 \mu \mathrm{g} / \mathrm{mL}$; C. albicans, amphotericin B $16 \mu \mathrm{g} / \mathrm{mL}$.

\begin{tabular}{llll}
\hline Compound & $\begin{array}{l}\text { S. aureus } \\
\text { ATCC 25923 }\end{array}$ & $\begin{array}{l}\text { E. coli } \\
\text { ATCC 25922 }\end{array}$ & $\begin{array}{l}\text { C. albicans } \\
\text { ATCC 90028 }\end{array}$ \\
\hline $\mathbf{1}$ & $45 \pm 0.03$ & $0 \pm 0.05$ & $-53 \pm 0.31$ \\
$\mathbf{2}$ & $13 \pm 0.28$ & $8 \pm 0.04$ & $20 \pm 0.13$ \\
$\mathbf{3}$ & $6 \pm 0.02$ & $6 \pm 0.06$ & $0 \pm 0.01$ \\
$\mathbf{4}$ & $-12 \pm 0.03$ & $11 \pm 0.04$ & $23 \pm 0.11$ \\
$\mathbf{5}$ & $-9 \pm 0.05$ & $6 \pm 0.04$ & $-8 \pm 0.08$ \\
$\mathbf{6}$ & $-1 \pm 0.24$ & $6 \pm 0.03$ & $-13 \pm 0.17$ \\
$\mathbf{7}$ & $-8 \pm 0.19$ & $3 \pm 0.03$ & $-35 \pm 0.06$ \\
$\mathbf{8}$ & $76 \pm 0.04$ & $9 \pm 0.06$ & $39 \pm 0.07$ \\
\hline
\end{tabular}

$\mathrm{MIC}_{90}$ and $\mathrm{IC}_{50}$ values against $S$. aureus were determined for compounds $\mathbf{1 , 8 , 9}$, and $\mathbf{1 0}$. Compound 9 had a weaker antimicrobial activity $\left(\mathrm{MIC}_{90}>125 \mu \mathrm{g} / \mathrm{mL}\right)$ than compounds $\mathbf{1}$ and $\mathbf{8}\left(\mathrm{MIC}_{90}=63\right.$ and $61 \mu \mathrm{g} / \mathrm{mL}$, respectively) against $S$. aureus, suggesting that the conjugated diene system of $\mathbf{1}$ is important for activity. However, compound 10, the 1a derivative containing a D-serine methyl ester 
side chain, had similar $\mathrm{MIC}_{90}(60 \mu \mathrm{g} / \mathrm{mL})$ as $\mathbf{1}$ and $\mathbf{8}$. We also measured the activity against methicillin-resistant S. aureus (MRSA), and it is noteworthy that compound $\mathbf{1 0}$ showed a 7.5-fold stronger inhibition against the resistant strain $\left(\mathrm{MIC}_{90} 8 \mu \mathrm{g} / \mathrm{mL}\right.$ ) than against $S$. aureus ATCC 25923. The $\mathrm{MIC}_{90}$ values of compounds 1 and 8 against MRSA were $31 \mu \mathrm{g} / \mathrm{mL}$ and $62 \mu \mathrm{g} / \mathrm{mL}$, respectively.

The demonstrated activity against $S$. aureus lead us to determine $\mathrm{MIC}_{90}$ values against an extended set of microorganisms. The set included pathogens usually found in spoiled food, infected skin and/or teeth, such as $S$. typhimurium, S. epidermidis, P. acnes, S. mitis, R. mucilaginosa and C. cladosporoides. These additional screening results are summarized in Table 2. It shows noteworthy activity of $\mathbf{1 0}$ against $S$. epidermidis and $S$. mitis $\left(\mathrm{MIC}_{90} 8 \mu \mathrm{g} / \mathrm{mL}\right)$. Previous work has described derivatives of $\mathbf{1}$ and 1a with comparable potency (MIC against $S$. aureus between 5 and $20 \mu \mathrm{M}$ corresponding to $\left.2-8 \mu \mathrm{g} / \mathrm{mL},,^{23,25}\right)$, and it has been suggested that compounds isolated from natural products could be considered interesting if their MIC lies below $10 \mu \mathrm{g} / \mathrm{mL} .^{26}$

Table 2. MIC $_{90}$ values $(\mu \mathrm{g} / \mathrm{mL})$ against extended set of bacteria and fungi for compounds $\mathbf{1}$, 8 , and $\mathbf{1 0}$ and antimicrobial agents used as positive controls.

\begin{tabular}{|c|c|c|c|c|c|c|}
\hline Compound & $\begin{array}{l}S . \\
\text { typhimurium }\end{array}$ & $\begin{array}{l}S . \\
\text { epidermidis }\end{array}$ & $\begin{array}{l}P . \\
\text { acnes }\end{array}$ & $\begin{array}{l}S . \\
\text { mitis }\end{array}$ & $\begin{array}{l}R . \\
\text { mucilaginosa }\end{array}$ & $\begin{array}{l}\text { C. } \\
\text { cladosporoides }\end{array}$ \\
\hline 1 & 31 & 3 & 4 & 16 & 31 & 63 \\
\hline 8 & $>125$ & 16 & $>125$ & $>125$ & 31 & $>125$ \\
\hline 10 & 31 & & 16 & 8 & 31 & $>125$ \\
\hline Ampicillin & 0.5 & 2 & 0.125 & 2 & & \\
\hline Chloramphenicol & 8 & & 4 & 4 & & \\
\hline Tetracyclin & & 1 & 2 & 1 & & \\
\hline Clarithromycin & & & 0.5 & 0.25 & & \\
\hline Fluconazole & & & & & 0.5 & 520 \\
\hline Nystatin & & & & & 0.125 & 64 \\
\hline
\end{tabular}

In this study, the most promising candidate in terms of antimicrobial activity was compound $\mathbf{1 0}$, which suggests beneficial influence of aromatic ring structure of $1 \mathbf{a}$ and D-serine methyl ester side chain on bioactivity. Compound $\mathbf{1 0}$ shows good activity especially against $S$. aureus (MRSA), S. epidermidis and S. mitis, but further studies would be required to elucidate in detail the observed biological activities. Detailed mode of action studies for this particular type of derivatives have not 
been reported. In general abietane-type compounds have been reported to interact with phospholipid membranes and membrane-bound enzymes, particularly effectively disrupting cell membranes of Gram-positive bacteria. ${ }^{11,27-30}$

\subsection{Cytotoxicity against mammalian cells}

The quality of an antibiotic candidate is not only determined by its capability to affect bacteria, but the compound must also be innocuous to human cells. Therefore, we conducted cytotoxicity experiments against mammalian cells to estimate the selectivity of the compound effects between microbial and mammalian cells.

The cytotoxicity of compounds 8-10 against non-cancerous BALB/c 3T3 cells was measured by MTT and LDH assays, and the $\mathrm{IC}_{50}$ values were determined based on the results from the MTT assay. $\mathrm{IC}_{50}$ values against BALB/c 3 T3 cells were very similar: compound $\mathbf{8}, 36 \mu \mathrm{g} / \mathrm{mL}$; compound $\mathbf{9}, 48 \mu \mathrm{g} / \mathrm{mL}$; and compound $\mathbf{1 0}, 45 \mu \mathrm{g} / \mathrm{mL}$. With the $\mathrm{IC}_{50}$ values against bacterial cells (S. aureus) in the same order of magnitude $(21-30 \mu \mathrm{g} / \mathrm{mL})$, there is no clear selectivity of the compounds between microbial and mammalian cells.

Using the LDH assay, we measured the increase in leakage of intracellular LDH as compared to the spontaneous release in untreated cells, which indicates the cell wall-damaging effect of the compounds. At higher compound concentrations (9 and $10>50 \mu \mathrm{g} / \mathrm{mL}, \mathbf{8}>36 \mu \mathrm{g} / \mathrm{mL}), \mathrm{LDH}$ leakage starts to increase in a concentration-dependent manner, suggesting that the observed effects for these compounds are very likely related to membrane disturbance (Supplementary material, Fig. A.1.).

The reported cytotoxicity of abietic acid 1 derivatives varies, and cytotoxic compounds with $\mathrm{IC}_{50}$ values below $10 \mu \mathrm{M}$ as well as relatively innocuous compounds with $\mathrm{IC}_{50}$ values above $100 \mu \mathrm{M}$ against both skin fibroblasts and human metastatic melanoma cells have been described. ${ }^{14}$ Within this context, the cytotoxicity of our derivatives seems to be at moderate level. Still, cytotoxicity against mammalian cells can be a serious unwanted effect of derivatives of $\mathbf{1}$, which highlights the need for evaluating it as early as possible.

\subsection{Bioactivity of related compounds}

Knowing that a broad spectrum of bioactivities has been described for abietic acid $\mathbf{1}$ and related compounds, we looked for entries of the compounds in this study in the online databases ChEMBL, 
PubChem and ChemSpider. We also crawled ChEMBL for chemically related compounds in an attempt to find background information on similar compounds. At the time of writing, neither ChEMBL, PubChem nor ChemSpider held a record for any of the compounds. ChEMBL lists three compounds with a similarity coefficient $>90$ : two of them are similar to 2-7 or 8 and one to 9 and 10 (Table 3). Within the similar compounds, bioactivity has been reported only for entry

ChEMBL496686 (see Supplementary material, Fig. A.2.), described as a neuroprotective agent that inhibits the activation of p38 MAPK and JNK in murine HT22 cells. ${ }^{31}$

In addition, based on our selection criteria, we downloaded the structures of 323 antibiotics from ChEMBL. However, none of them showed a similar fingerprint to abietic acid 1 or its derivatives (max value: 0.22 ). While a high similarity would have been useful for the elucidation of the mode of action, the absence is also encouraging; 1 and/or its derivatives may act in a novel way to be explored in future studies.

Table 3. Bioactivity of similar compounds retrieved from ChEMBL. ${ }^{a}$

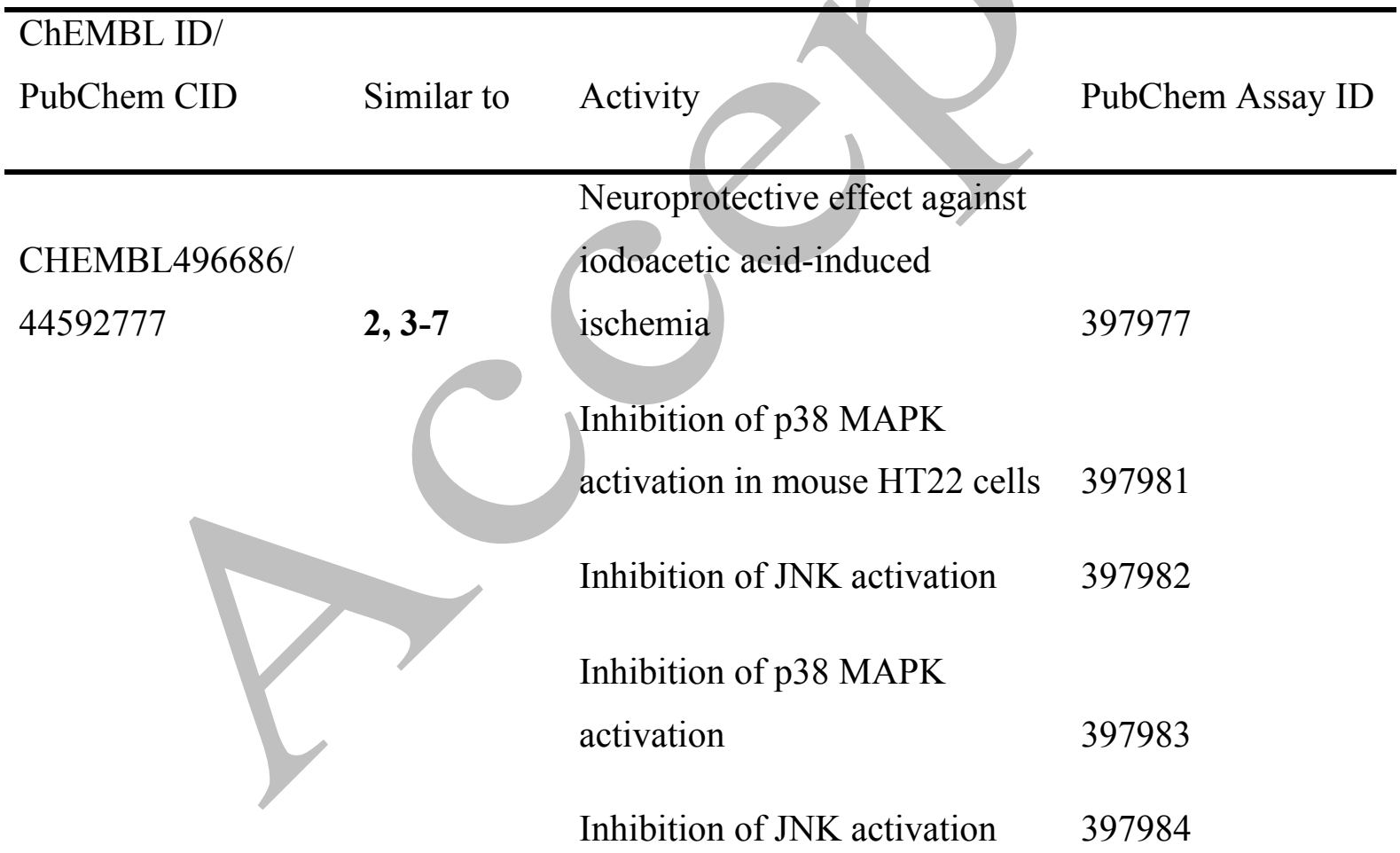

CHEMBL496869/

$44592778 \quad \mathbf{2}, \mathbf{3 - 5}, \mathbf{8}, \quad$ None 
CHEMBL3289363/

90681715

9-10

None

${ }^{\mathrm{a}}$ Compounds with a similarity $>90$ are listed.

\section{Conclusions}

In this study, we have identified the serine derivatives (8 and 10) of $\mathbf{1}$ and $\mathbf{1 a}$ with good antimicrobial properties against Gram-positive bacteria. However, the compounds were poorly selective towards bacterial cells and caused cell membrane damage at high concentrations by inducing intracellular LDH leakage. The activity of compound $\mathbf{1 0}$ against important pathogens such as MRSA, S. epidermidis and S. mitis was nonetheless noteworthy. Our results highlight the potential of $\mathbf{1}$ and $\mathbf{1 a}$ as a starting point for the development of new antimicrobial agents. The risk to induce resistance is low due to apparently fast-killing membrane targeting effects. Future efforts should focus on optimization of their potency and selectivity, and on studying their activity against a broader microbial spectrum as well as other pathologic targets.

\section{Acknowledgements}

This work was supported by the European Union Seventh Framework Programme FP7 WoodWisdom-Net+ under Academy of Finland grant agreement no. 256515 (GREASE) and TUBITAK 110O951. AH and PT (Grant no. 277001 and 284477) and JYK (Grants no. 264020 and 265481) were also supported by the Academy of Finland. VMM thanks the Magnus Ehrnrooth Foundation (project ME2012n44) for financial support. 


\section{References}

1. Hebert, C.; Weber, S. G. Infect. Dis. Clin. North Am. 2011, 25, 181-200.

2. Bérdy, J. J. Antibiot. 2012, 65, 385-395.

3. Gu, W.; Wang, S. Eur. J. Med. Chem. 2010, 45, 4692-4696.

4. Gigante, B.; Santos, C.; Silva, A. M.; Curto, M. J. M.; Nascimento, M. S. J.; Pinto, E.; Pedro, M.;

Cerqueira, F.; Pinto, M. M.; Duarte, M. P.; Laires, A.; Rueff, J.; Gonçalves, J.; Pegado, M. I.; Valdeira, M.

L. Bioorg. Med. Chem. 2003, 11, 1631-1638.

5. Leandro, L. F.; Cardoso, M. J. O.; Silva, S. D. C.; Souza, M. G. M.; Veneziani, R. C. S.; Ambrosio, S. R.; Martins, C. H. G. J. Med. Microbiol. 2014, 63, 1649-1653.

6. San Feliciano, A.; Gordaliza, M.; Salinero, M. A.; del Corral, J. M. Planta Med. 1993, 59, 485-490.

7. Caetano da Silva, S. D.; Mendes de Souza, M. G.; Oliveira Cardoso, M. J.; da Silva Moraes, T.;

Ambrósio, S. R.; Sola Veneziani, R. C.; Martins, C. H. G. Anaerobe 2014, 30, 146-152.

8. Goodson, B.; Ehrhardt, A.; Ng, S.; Nuss, J.; Johnson, K.; Giedlin, M.; Yamamoto, R.; Moos, W. H.;

Krebber, A.; Ladner, M.; Giacona, M. B.; Vitt, C.; Winter, J. Antimicrob. Agents Chemother. 1999, 43, $1429-1434$.

9. Savluchinske-Feio, S.; Nunes, L.; Pereira, P. T.; Silva, A. M.; Roseiro, J. C.; Gigante, B.; Marcelo Curto, M. J. J. Microbiol. Methods 2007, 70, 465-470.

10. Savluchinske-Feio, S.; Curto, M. J. M.; Gigante, B.; Roseiro, J. C. Appl. Microbiol. Biotechnol. 2006, $72,430-436$.

11. Manner, S.; Vahermo, M.; Skogman, M. E.; Krogerus, S.; Vuorela, P. M.; Yli-Kauhaluoma, J.;

Fallarero, A.; Moreira, V. M. Eur. J. Med. Chem. 2015, 102, 68-79.

12. Moreira, V. M.; Fallarero, A.; Yli-Kauhaluoma, J.; Vuorela, P.; Vahermo, M. Patent WO2016051013A1, 2016.

13. Olmo, F.; Guardia, J. J.; Marin, C.; Messouri, I.; Rosales, M. J.; Urbanová, K.; Chayboun, I.; Chahboun, R.; Alvarez-Manzaneda, E. J.; Sánchez-Moreno, M. Eur. J. Med. Chem. 2015, 89, 683-690.

14. Sadashiva, M. P.; Gowda, R.; Wu, X.; Inamdar, G. S.; Kuzu, O. F.; Rangappa, K. S.; Robertson, G. P.; Gowda, D. C. Exp. Parasitol. 2015, 155, 68-73. 
15. Vahermo, M.; Krogerus, S.; Nasereddin, A.; Kaiser, M.; Brun, R.; Jaffe, C. L.; Yli-Kauhaluoma, J.; Moreira, V. M. Med. Chem. Commun., 2016, 7, 457-463.

16. Huang, X.-C.; Wang, M.; Wang, H.-S.; Chen, Z.-F.; Zhang, Y.; Pan, Y.-M. Bioorg. Med. Chem. Lett. $2014,24,1511-1518$.

17. Ukiya, M.; Kawaguchi, T.; Ishii, K.; Ogihara, E.; Tachi, Y.; Kurita, M.; Ezaki, Y.; Fukatsu, M.; Kushi, Y.; Akihisa, T. Chem. Biodivers. 2013, 10, 1260-1268.

18. NCCLS, Reference method for broth dilution antifungal susceptibility testing of yeasts; Approved standard, second ed., 2002, Vol. 22.

19. CLSI, Methods for dilution antimicrobial susceptibility tests for bacteria that grow aerobically: Approved standard. 2009, 28, 1-35.

20. Mosmann, T. J. Immunol. Methods 1983, 65, 55-63.

21. Promega, CytoTox-ONE Homogeneous Membrane Integrity Assay. https://fi.promega.com/resources/protocols/technical-bulletins/101/cytotox-one-homogeneous-membraneintegrity-assay-protocol/, 2016 (accessed 14.10.2016).

22. Ukiya, M.; Kikuchi, T.; Tokuda, H.; Tabata, K.; Kimura, Y.; Arai, T.; Ezaki, Y.; Oseto, O.; Suzuki, T.; Akihisa, T. Chem. Biodivers. 2010, 7, 1871-1884.

23. Dellar, J. E.; Cole, M. D.; Waterman, P. G. Phytochem. 1996, 41, 735-738.

24. Bicho, P. A.; Martin, V.; Saddler, J. N. Appl. Environ. Microbiol. 1995, 61, 3245-3250.

25. Goodson, B.; Ehrhardt, A.; Ng, S.; Nuss, J.; Johnson, K.; Giedlin, M.; Yamamoto, R.; Moos, W. H.; Krebber, A.; Ladner, M.; Giacona, M. B.; Vitt, C.; Winter, J. Antimicrob. Agents Chemother. 1999, 43, $1429-1434$.

26. Ríos, J. L.; Recio, M. C. J. Ethnopharmacol. 2005, 100, 80-84.

27. Aranda, F. J.; Villalaín, J. Biochim. Biophys. Acta 1997, 1327, 171-180.

28. Ganewatta, M. S.; Miller, K. P.; Singleton, S. P.; Mehrpouya-Bahrami, P.; Chen, Y. P.; Yan, Y.; Nagarkatti, M.; Nagarkatti, P.; Decho, A. W.; Tang, C. Biomacromolecules 2015, 16, 3336-3344.

29. González, M. A. Eur. J. Med. Chem. 2014, 87, 834-842.

30. Sekido, H.; Takezawa, J.-I.; Motoki, G.; Akatsuka, T. Agric. Biol. Chem. 1990, 54, 287-290.

31. Biraboneye, A. C.; Madonna, S.; Laras, Y.; Krantic, S.; Maher, P.; Kraus, J.-L. J. Med. Chem. 2009, 52, 


$$
P^{e^{e e^{e^{e^{d}}}}}
$$

